\title{
10 JAHRE UNCTAD
}

\author{
Von Martin Ruge
}

\section{Der „Süden“ formiert sich}

Mit der Einberufung der Welthandelskonferenz, United Nations Conference on Trade and Development (= UNCTAD), am 23. März 1964 nach Genf zeichnet sich eine grundlegende Verschiebung des Spannungsfeldes auf der internationalen Bühne ab. Erstmals gelingt es den Staaten der Dritten Welt unter der energischen Führung von Raúl Prebisch, dem ehemaligen Executive Secretary der UN-Wirtschaftskommission für Lateinamerika (ECLA), das Entwicklungsproblem als Kardinalproblem unserer Tage in das Bewußtsein einer aufgeschreckten Weltöffentlichkeit zu tragen. Am Ende der mehrmonatigen Konferenz ist mit der „Gruppe der 77" eine einheitliche Front der Entwicklungsländer entstanden. Gegen die Stimmen eines erheblichen Teils der Industriestaaten werden grundlegend neue Prinzipien für eine gerechtere Weltwirtschaftsordnung ohne materielle Diskriminierung derEntwicklungsländer entworfen ${ }^{1}$ und die Errichtung von UNCTAD als ständiger Pressure Group des „Südens“ im Rahmen der handels- und entwicklungspolitischen Auseinandersetzung mit dem industriellen „Norden" durchgesetzt. Die moralische Stärke und das Sendungsbewußtsein der Entwicklungsländer, die als Vertreter der unterprivilegierten zwei Drittel der Menschheit auftreten, findet in UNCTAD einen Kristallisationspunkt für die Durchdringung der UN und ihrer Spezialorganisationen mit dem Ziel ihrer nahezu ausschließlichen Ausrichtung auf das Entwicklungsproblem. Die Gründung von UNCTAD bezeichnet damit den ersten durchschlagenden Erfolg der Bemühungen einer expolosionsartig gewachsenen Zahl unabhängig gewordener Staaten der Dritten Welt um eine angemessene Interessenvertretung im Bereich der internationalen Wirtschaftsbeziehungen.

\section{UNCTAD's institutionelle Eigenart}

Juristisch geschickt als ein über das allgemeine UN-Budget finanziertes Hilfsorgan der Vollversammlung lanciert ${ }^{2}$, gleich die UNCTAD nach Größe und universeller Mitgliedschaft einer Spezialorganisation. Sie weist jedoch ihrer besonderen Zielsetzung wegen entscheidende Eigenheiten auf. UNCTAD ist die erste Organisation der Vereinten Nationen, die sich ausschließlich dem Entwicklungsproblem widmet und in der die Entwicklungsländer die absolute Mehrheit besitzen. Mit der Kombination von periodischen Vollkonferenzen (1964 in Genf, 1968 in NeuDelhi, 1972 in Santiago), regelmäßigen Sitzungen des Welthandelsrates und der permanenten Tätigkeit des Sekretariats in Genf verfügt UNCTAD über ein bemerkenswertes Instrumentarium für sowohl publikumswirksame Aktionen als auch die technische Arbeit am handelspolitischen Detail. UNCTAD stellt damit schon von ihrem institutionellen Zuschnitt her den ersten erfolgversprechenden Versuch dar, auf universeller Grundlage, insbesondere unter Einschluß auch der

$1 \mathrm{Vgl}$. die als Anhang I abgedruckten ${ }_{n}$ Allgemeinen Prinzipien ${ }^{\alpha}$ von UNCTAD I.

2 Vgl. die Gründungsresolution GA 1995 (XIX), abgedruckt als Anhang II. 
Staatshandelsländer, gemeinsame Grundsätze für die internationalen Wirtschaftsbeziehungen aufzustellen und zu verwirklichen, die auch den Entwicklungsländern das Erwirtschaften eines angemessenen Anteils am wachsenden Weltbruttosozialprodukt ermöglichen sollen. UNCTAD realisiert hierbei in umfassender Weise ein Projekt, das in Gestalt der "International Trade Organization" (ITO) und deren ebenso glückloser Nachfolgerin "Organization for Trade Cooperation" (OTC) in den ersten Nachkriegsjahren an dem ausgeprägten Mißtrauen des amerikanischen Kongresses gegen jede Form internationaler Wirtschaftslenkung gescheitert war.

\section{Ansätze zu globaler Entwicklungsplanung}

Die Gesamtheit der Aktivitäten von UNCTAD stand von vornherein unter dem Vorzeichen der noch von Raúl Prebisch entworfenen Globalstrategie, deren Grundzüge in die Zweite Entwicklungsdekade der Vereinten Nationen eingegangen sind. Darin wird erstmalig ein Ansatz zu globaler Entwicklungsplanung sichtbar. Das Entwicklungsproblem wird als Gemeinschaftsaufgabe von Entwicklungs- und Industriestaaten gesehen. Das unmittelbare Eigeninteresse der Entwicklungsländer sowie das langfristige Interesse der Industriestaaten an einer sicheren Zukunft sollen unter dem Stichwort der „new reciprocity“ die solide Grundlage der entstehenden und in den Artikeln 55 und 56 der UN-Charta bereits angelegten Weltsozialgemeinschaft bilden. Dies hat nichts mit einer vorläufig noch utopischen Weltstaatsromäntik zu tun. Das von den Großmächten ausgeübte Machtmonopol bleibt unberührt. Jedoch stehen inzwischen, wie jedermann dank weltumspannender Kommunikationsmittel weiß, die wissenschaftlich-technologischen Mittel zur Verfügung, um die wirtschaftlichen und sozialen Probleme des übermäßigen Entwicklungsgefälles von Nord nach Süd global, wenn auch azentral, zu lösen. Die Gründung von UNCTAD dokumentiert den unbedingten Willen der Entwicklungsländer, diese Mittel unter ihrer planerischen Mitwirkung zum Einsatz zu bringen.

\section{Das Gruppensystem}

Die Tätigkeit von UNCTAD besteht weitgehend darin, die Industriestaaten unter ständiger Betonung der gemeinsamen Verantwortung für die Lösung des Entwicklungsproblems auf allen für die internationalen Wirtschaftsbeziehungen relevanten Gebieten zu einer - meist kostspieligen - entwicklungsfreundlichen Haltung zu veranlassen. $\mathrm{Da}$ auch mit hohen Mehrheiten verabschiedete Beschlüsse von UNCTAD nur empfehlenden Charakter haben und derartige Empfehlungen mangels einer ausreichenden machtpolitischen Position der Entwicklungsländer auch nicht faktisch erzwungen werden können, ist UNCTAD auf die Möglichkeiten des syndikalistischen Lobbying angewiesen. Dem entspricht das in dieser Organisation erstmals institutionalisierte Gruppensystem, das der „Gruppe der 77“ die Rolle des - vom Sekretariat unterstützten und beratenen - Motors der entwicklungsfreundlichen Willensbildung ermöglicht, während die Nordstaaten, in Ost und West geteilt, Adressat zahlreicher, nach ihren Wirtschaftssystemen differenzierten Forderungen sind und nicht selten gegeneinander ausgespielt werden. Nur die Eigenorganisation der Entwicklungsländer Lateinamerikas, Afrikas und Asiens in 
der "Gruppe der 77 “ bietet - unter ständiger Vermittlung des UNCTAD-Sekretariats - die Chance, die außerordentlich disparaten Interessen der einzelnen Entwicklungsländer zu kaschieren und eine geschlossene Plattform gegenüber den Nordstaaten zu bilden. Die den jeweiligen Vollkonferenzen vorangehenden Treffen der „Gruppe der 77“ dienen demselben Ziel.

\section{Ơffentlichkeitsarbeit mit moralischem Anspruch}

Den Solidarisierungseffekt des Gruppensystems ergänzt eine intensive Offentlichkeitsarbeit von UNCTAD besonders in den westlichen Industriestaaten. Damit wird einer Gegensolidarisierung vorgebeugt und der Versuch unternommen, die fehlende „Tariffähigkeit" der Entwicklungsländer durch die Mobilisierung der öffentlichen Meinung in den Industriestaaten wenigstens teilweise zu ersetzen.

Der unmittelbare Rückgriff auf das Rechtsgefühl vor dem Hintergrund einer Weltwirtschaftsordnung, die den Abstand zwischen Nord und Süd tendenziell verstärkt, hat insbesondere bei der jüngeren Generation in den westlichen Industriestaaten großen Widerhall gefunden. Selbst relativ technische handelspolitische Themen, die sonst gerne „den Experten“ überlassen werden, erhalten im Zusammenhang mit dem Entwicklungsproblem - wie Erich Fromm sagen würde „bio-phile“ Züge.

Während das Wirtschaftswachstum im (westlichen) Norden zunehmend als langweiliger bis schädlicher Selbstzweck begriffen wird, beinhaltet es im Süden noch das lebendig-sinnvolle Ziel der Befreiung von Hunger und äußerer Abhängigkeit.

Die Institutionalisierung der Entwicklungshilfe in den Haushalten und Kabinetten aller westlichen Industriestaaten trotz weitgehenden Wegfalls der militärpolitischen Motive ist entscheidend mit auf die zahllosen von UNCTAD inspirierten Dritte-Welt-Initiativen zurückzuführen, die, von den Kirchen unterstützt, das Entwicklungsproblem als Gegenstand moralischer Bewährung des Nordens verstehen.

\section{Ordnungsprinzip auf der Grundlage autonomer Gruppenbildung}

Die Instituionalisierung des Gruppensystems mit der Unterteilung in Süd („Gruppe der 77“), West (OECD-Mitglieder mit geringfügigen Abweichungen) und Ost (COMECON-Mitglieder mit geringfügigen Abweichungen) beinhaltet schließlich den Entwurf eines neuen Ordnungsprinzips für die internationalen Wirtschaftsbeziehungen mit völkerrechtlicher Qualität.

Entscheidend neues Element dieses Ordnungsprinzips ist der doppelte Anspruch der Entwicklungsländer darauf, in allen entwicklungspolitisch erheblichen Bereichen trotz ihrer machtpolitisch schwachen Stellung als autonome Gruppe

- gleichberechtigt mitbestimmen zu können und

- bevorzugt behandelt zu werden.

UNCTAD hat diesem Anspruch in weiten Bereichen zur Anerkennung verholfen. Die zahlenmäßige Verstärkung der Entwicklungsländervertreter im Wirtschaftsund Sozialrat, die zunehmende Berücksichtigung von Entwicklungsländerinteressen durch das GATT seit der Einfügung des „Teil IV“ in das GATT-Abkommen im Jahre 1964, die Erweiterung des „Zehnerklubs“ beim Weltwährungsfonds, die 
Gründung von UNITAR (United Nations Institute for Administration and Research), UNIDO (United Nations Industrial Development Organization) und des „Capital Development Fund" sind äußere Anzeichen für eine - gerade auch von UNCTAD geforderte - verstärkte Mitbestimmung des „Südens“ in allen mit Entwicklungsproblemen befaßten Gremien. Eine letzte „Bastion“ des (Nord-)Westens bildet die Weltbankgruppe (IBRD, IFC, IDA), in deren Bereich die Anzahl der Stimmen eines Mitglieds von der Größe der einbezahlten Kapitalanteile abhängt. Das Beispiel des Währungsfonds und die Ergebnisse des Pearson-Berichts lassen aber auch hier eine Tendenz zur Verstärkung des Entwicklungsländereinflusses erwarten.

Es gibt kaum einen weltwirtschaftlich und völkerrechtlich bedeutsamen Bereich mehr, in dem nicht aufgrund von Absprachen im Rahmen der "Gruppe der 77" und sachkundiger Beratung durch das UNCTAD-Sekretariat Sonderınteressen der Entwicklungsländer geltend gemacht und - teilweise - durchgesetzt werden.

Im Bereich der Entwicklungsfinanzierung ist UNCTAD Schrittmacherin des Gedenkens einer - zunächst freiwilligen - „Entwicklungsabgabe“ in Höhe von einem Prozent des Bruttosozialprodukts der Industriestaaten, wovon ab 1975 0,7 Prozent auf die öffentliche Entwicklungshilfe entfallen sollen.

Die Stabilisierung und Verbesserung der Rohstoffpreise erreicht UNCTAD auf verschiedenen Wegen. Während für Produkte mit starker Marktstellung wie Rohöl, Kupfer und Zinn eigene Produzentenverbände gewissermaßen als Einzelgewerkschaften tätig sind (OPEC, CIPEC und der Zinnrat), fördert UNCTAD unmittelbar den Abschluß von Rohstoffabkommen für marktschwache Produkte mit preisstabilisierender Wirkung (z. B. die Zuckerkonferenzen) und regt Notfinanzierungsmaßnahmen zum Ausgleich von "unvorhersehbaren Exportausfällen“ an, um eine kontinuierliche Entwicklungsfinanzierung zu erreichen („supplementary and compensatory financing"). Der bemerkenswerte preispolitische Erfolg der arabischen Ölproduzenten in jüngster Zeit ist nicht zuletzt auf das von UNCTAD geförderte Selbstbewußtsein der Entwicklungsländer und das durch UNCTAD vorgelebte Modell gewerkschaftsähnlichen Vorgehens im internationalen Bereich zurückzuführen. Längerfristig dürften auch die legitimen entwicklungspolitischen Forderungen der arabischen Staaten die unglückliche tagespolitische Verwendung des Öls als Druckmittel im Nahostkonflikt überdauern. Bereits jetzt zeichnen sich Lösungsmöglichkeiten $a b$, die letztlich auf den Bestimmungen des VI. Kapitels der Havanna-Charta aufbauen, die UNCTAD-Prinzipien zur Stabilisierung der „Terms of Trade“ berücksichtigen und die tarifvertragsähnliche Festsetzung der „fair prices" zum Gegenstand haben. Das Organisationsmodell von UNCTAD könnte dabei auch vom institutionellen Ansatz her wertvolle Dienste leisten.

Im Bereich des Handels mit Halbfertig- und Fertigwaren ist UNCTAD nach sechsjährigem zähem Ringen die Vereinbarung eines allgemeinen Präferenzabkommens zugunsten der Entwicklungsländer gelungen. Dies bedeutet im Nord-SüdVerhältnis gleichzeitig den Abschied von den in erster Linie für die westlichen Industriestaaten effektiven und profitablen GATT-Prinzipien der Meistbegünstigung und der Gegenseitigkeit und die teilweise Umgestaltung der Welthandelsordnung zu einem spezifischen Entwicklungsinstrument. Das „Generalized System of Preferences" (GSP) ist zudem das erste konkrete Beispiel für die Herausbildung des völkerrechtlichen Sonderstatus „Entwicklungsland“. In Anlehnung an das Gruppensystem wurden automatisch alle Mitglieder der "Gruppe der $77^{\text {“ als }}$ 
präferenzberechtigte Entwicklungsländer anerkannt. Nichtmitglieder wie Israel und Rumänien mußten sich dagegen um eine Anerkennung als Entwicklungsland bei den einzelnen präferenzgewährenden Industriestaaten bemühen. Parallel den Bemühungen um die Einführung und Verbesserung des Präferenzabkommens streitet UNCTAD in ähnlicher Weise für eine Begünstigung der Entwicklungsländer in der internationalen Seeschiffahrt, und zwar sowohl hinsichtlich der Frachtraten als auch der Verteilung des Frachtaufkommens.

Selbst auf Gebieten, die eigentlich außerhalb ihres Zuständigkeitsbereichs liegen, übt UNCTAD wegen ihrer Funktion als "Gewerkschaft der Entwicklungsländer" einen erheblichen Einfluß aus. Dies gilt etwa für den Vorschlag, im Zuge der Reform des Weltwährungssystems vermehrte Sonderziehungsrechte zur Finanzierung von Entwicklungsprojekten zu verwenden („the link“). Auch zur künftigen Nutzung des Meeresbodens entwickelt UNCTAD eigene Vorstellungen, die auf eine Sicherung der Interessen der technologisch noch weniger fortgeschrittenen Staaten abzielen. Ebenso selbstbewußt machten die Mitgliedstaaten der „Gruppe der 77" auf der Umweltschutzkonferenz 1972 in Stockholm klar, daß internationale Umweltschutznormen den sozioökonomischen Nachholbedarf der Entwicklungsländer berücksichtigen müssen.

\section{Autonome Gruppenbildung contra hegemoniale Grofraumordnung}

Die Anerkennung des Rechts der Entwicklungsländer auf gleichberechtigte Mitgestaltung der internationalen Wirtschaftsbeziehungen und auf Berücksichtigung ihrer legitimen Sonderinteressen markiert eo ipso die allmähliche Abkehr von einer regionalistischen Großraumordnung, wie sie sich in den ersten beiden Jahrzehnten nach dem 2. Weltkrieg mit der Orientierung Lateinamerikas nach den USA, Afrikas nach Europa und Südostasiens nach Japan abzeichnete. Das Gruppensystem ermöglicht im "Süden“ eine autonome Gruppenbildung auf regionaler und subregionaler Ebene unter Abschwächung hegemonialer Einflüsse. Damit stärkt das Gruppensystem im „Süden“ die einzelstaatliche Souveränität in ihrer Qualität als freiheitsbewahrendes Abwehrrecht, transzendiert sie aber gleichzeitig weltweit unter dem Gesichtspunkt des Entwicklungsproblems als einer Gemeinschaftsaufgabe der ,international community“.

Dieses Konzept der autonomen Gruppenbildung fördert UNCTAD auf regionaler und sub-regionaler Ebene seit der Konferenz von Neu-Delhi (1968) gezielt unter den Stichworten „Handelsausweitung und regionale Wirtschaftsintegration ${ }^{3 \text { “. Die }}$ Unterstützung zahlreicher regionaler und sub-regionaler Gruppierungen von Entwicklungsländern und der entsprechenden multilateralen Finanzierungsinstitute gehört ebenso in diesen Zusammenhang wie die Hilfe bei der Errichtung von regionalen Zahlungsunionen und gemeinsamen Versicherungseinrichtungen. In der regionalen Zusammenarbeit von Entwicklungsländern untereinander sieht UNCTAD zugleich einen maßgeblichen Beitrag zur Selbsthilfe, auf den gern verwiesen wird, wenn es gilt, den Industriestaaten neue Zugeständnisse abzuringen.

Das von UNCTAD institutionalisierte Gruppensystem weist auch den Weg zur Uberwindung der Sterilität des „one state, one vote“-Verfahrens, wie es in der

3 Vgl. die "Concerted Declaration" von Neu-Delhi = UNCTAD Res. 23 (II), abgedruckt als Anhang III. 
Vollversammlung und dem Wirtschafts- und Sozialrat der Vereinten Nationen bis zum Exzeß geprobt wird. Die Ansätze zu konzertierten Aktionen von Ost, West und Süd im Entwicklungsbereich lassen - vielleicht erstmals seit den Tagen des „Europäischen Konzerts“ - das Heraufkommen einer wenigstens in langfristigen Überlebensfragen solidarischen Staatengemeinschaft erahnen. Bemerkenswert ist dabei die Tatsache, daß - nicht zuletzt dank UNCTAD - schon jetzt den Staaten mit besonders ausgeprägten Strukturproblemen mit Rücksicht auf ihre Entwicklungsschwäche Sonderrechte eingeräumt werden. Nach weitgehendem Abschluß der Entkolonialisierungsphase und der damit verbundenen Erlangung der formellen Gleichheit seitens der "neuen Staaten“ beginnt damit eine Entwicklung, wie sie nur aus einem materiellen Gleichheitsverständnis heraus zu erklären ist, das jeder Sozialgemeinschaftsidee zugrunde liegt. Gleichzeitig bedeutet dies den Beginn einer Abkehr von der schrankenlosen Geltung des Effektivitätsprinzips im Völkerrecht. Mit der Anerkennung eines dynamischen Entwicklungskonzepts erhält das Völkerrecht zunehmend eine soziale, d. h. gemeinschaftsbezogene Funktion, wie dies in Art. 55 und 56 der UN-Charta richtungweisend niedergelegt ist.

UNCTAD hat dabei das unbestreitbare Verdienst, diese Zusammenhänge für alle Welt sichtbar gemacht und erste Erfolge bei der Ausrichtung der Weltwirtschaftsordnung auf das Ziel einer Weltsozialgemeinschaft erzielt zu haben.

\section{Ungelöste Probleme - die Rolle der multinationalen Unternehmen}

Der mit der Gründung von UNCTAD verfolgte große Entwurf einer gerechteren, d. h. die Interessen der sozio-ökonomisch schwachen Staaten besonders berücksichtigenden Weltwirtschaftsordnung wird allerdings trotz aller Bemühungen erst in den Grundzügen sichtbar. Die bisherigen Erfolge, namentlich das Allgemeine Präferenzsystem (GSP), begünstigen vorwiegend die schon relativ stark entwickelten „Schwellenmächte“. So ist beispielsweise der gesamte Bereich der Agrarprodukte von den Zollpräferenzen ausgenommen. Die Sonderförderung der 25 „Ärmsten der Armen" (least developed countries) läuft gerade erst an. Das 1-Prozent-Ziel für den Umfang der Entwicklungshilfe wird bei weitem nicht erreicht. Nichttarifäre Handelshemmnisse zu Lasten der Entwicklungsländer bestehen noch in erheblichem Umfange. Vor allem aber beginnt UNCTAD erst, die Rolle der multinationalen Unternehmen in Handel und Entwicklung zu untersuchen. Während auf Beschluß der Konferenz von Santiag॰ (1972) eine Definition der wirtschaftlichen Rechte und Pflichten der Staaten versucht wird ${ }^{4}$, sind entwicklungspolitisch wünschenswerte Verhaltensstandards für multinationale Unternehmen noch nicht in Sicht. Diese bestreiten aber den Löwenanteil des Welthandels und der Privatinvestitionen, die wiederum den größten Teil der Gesamtkapitalzuflüsse in die Entwicklungsländer ausmachen. Nachdem zumindest die westlichen Industriestaaten inzwischen eine echte Mitverantwortung für die Lösung des Weltentwicklungsproblems anerkennen, besteht die Gefahr, daß die multinationalen Unternehmen als faktische Hauptträger des internationalen Handels und der ausländischen Investitionen in Entwicklungsländern sich dieser Verantwortung entziehen. Angesichts der zunehmenden Verstärkung der Rechtsposition multinationaler Unternehmen auch im völkerrechtlichen Bereich - so können z. B. derartige Unternehmen Partei eines

4 Vgl. UNCTAD Res. 45 (III), abgedruckt als Anhang IV. 
Verfahrens vor dem von der Weltbank 1965 gegründeten „International Centre for the Settlement of Investment Disputes" sein - drängt sich die Frage auf, ob nicht auch eine völkerrechtliche Sozialpflichtigkeit multinationaler Unternehmen angenommen werden muß. Danach wäre dann etwa die Zulässigkeit wettbewerbsbeschränkender Maßnahmen an deren Auswirkungen auf die entwicklungspolitischen Anstrengungen der betroffenen Entwicklungsländer zu messen.

Erste Untersuchungen von UNCTAD in dieser Richtung liegen für Lateinamerika bereits vor.

Längerfristig wird UNCTAD versuchen müssen, das Entwicklungsproblem zu einer Gemeinschaftsaufgabe der „erweiterten internationalen Gemeinschaft“ unter Einschluß der multinationalen Unternehmen zu machen. Hieraus ließe sich dann auch eine Verpflichtung der multinationalen Unternehmen zur Zahlung eines an ihrem Konzernumsatz orientierten Entwicklungsbeitrags herleiten. Die Beitragshöhe könnte sich nach dem Durchschnitt der von den Industriestaaten geleisteten öffentlichen Entwicklungshilfe als Prozentsatz ihres Bruttosozialprodukts richten (die BRD leistete z. B. im Jahre 1973 öffentliche Entwicklungshilfe in Höhe von 0,3\% des Bruttosozialprodukts gegenüber den von UNCTAD ab 1975 geforderten 0,7\%). Die Mitheranziehung der multinationalen Unternehmen erscheint auch deswegen besonders gerechtfertigt, weil diese die sich aus dem Entwicklungsgefälle und der unterschiedlichen Steuergesetzgebung ergebenden Standortvorteile voll ausnutzen können.

\section{Parallelen und Unterschiede zur nationalen Sozialgemeinschaftsentwicklung}

Die Auswirkungen des von UNCTAD mit Erfolg institutionaliserten Gruppensystems erweisen überraschende Parallelen zwischen der Sozialgemeinschaftsentwicklung in den europäischen Nationalstaaten des 19. Jahrhunderts und der gegenwärtig sich abzeichnenden Entwicklung zur Weltsozialgemeinschaft. Ausgangspunkt war jeweils der Abschluß der politischen Emanzipationsbewegung verbunden mit den Problemen der einsetzenden Industrialisierung und der damit einhergehenden Zerstörung bestehender Sozial- und Wirtschaftsstrukturen. Hieraus ergab sich die Notwendigkeit, die nunmehr formell gleichberechtigten, aber materiell und institutionell unterprivilegierten Rechtssubjekte - hier Arbeiter, dort Entwicklungsländer als Treuhänder der armen Massen des Südens - besonders zu schützen und zu fördern. Die einsetzende Eigenorganisation der Unterprivilegierten förderte eine am langfristigen Eigeninteresse der führenden Schichten orientierte Sozialpolitik der jeweils größeren gesellschaftlichen Einheiten und führte zu den heutigen Modellen moderner Sozialgemeinschaften. Im internationalen Bereich ergibt sich die zusätzliche Schwierigkeit, daß mangels einer dem Nationalstaat des 19. Jahrhunderts vergleichbaren Weltexekutive die Initiativen zur Herausbildung einer Weltsozialgemeinschaft vom Konsensus der dadurch hauptsächlich finanziell belasteten Industriestaaten aus West und Ost getragen sein muß. UNCTAD war und ist deswegen kein normatives Forum im technischen Sinne, sondern ein integratives System mit dem Ziel verstärkter Gemeinschaftsbildung. Das von UNCTAD institutionalisierte Gruppensystem erweist sich dabei als geeigneter Integrationsrahmen in einer Situation, in der - ähnlich wie im kollektiven Arbeitsrecht die beteiligten Interessentengruppen keiner Dritten Gewalt eindeutig unterworfen sind. 


\section{Die nächsten 10 Jahre}

Noch wird jedoch der Abstand zwischen Entwicklungs- und Industriestaaten eher größer als kleiner; noch sinkt der Welthandelsanteil der Entwicklungsländer; noch expandiert der „Norden“ zu Lasten des „Südens“, wenn auch steigende Preise wichtiger Rohstoffe und ein verstärktes Umweltbewußtsein ein Abflachen der nördlichen Wachstumsraten erwarten lassen. Der permanente Planungsentwurf einer kooperativen und sinnvoll arbeitsteiligen Gesamtentwicklung der internationalen Gemeinschaft im Bereich von Handel und Entwicklung verlangt von UNCTAD weiterhin die Fähigkeit, jenseits der Abwicklung zahlreicher Mammutkonferenzen und der Bewältigung einer steigenden Flut von Dokumenten und Memoranden die große Idee der Anerkennung und Durchsetzung des Sozialgemeinschaftsprinzips auch im Bereich der internationalen Wirtschaftsbeziehungen mit Phantasie und Mut zur Konfrontation zu verfolgen.

Dabei wird UNCTAD - den ständigen Mahnungen ihres geistigen Vorkämpfers Raúl Prebisch folgend - zunehmend auch den möglichen Eigenbeitrag zahlreicher Entwicklungsländer bei der Verwirklichung eines solchen Sozialgemeinschaftsprinzips auf regionaler und sub-regionaler Ebene betonen müssen. Von der Bereitstellung eines Teils der aus dem Verkauf von knappen Rohstoffen erzielten Gewinne für gemeinsame Entwicklungsvorhaben über die Sonderförderung besonders entwicklungsschwacher Mitgliedsstaaten einer Regionalgruppe bis hin zur Entwicklung und Verbreitung energie- und kapitalextensiver, aber arbeitsintensiver Technologien durch die relativ fortgeschrittenen Entwicklungsländer reicht die Palette möglicher Initiativen von Entwicklungsländern für Entwicklungsländer. Testfall für die Kraft des von UNCTAD propagierten Sozialgemeinschaftsprinzips wird das Verhalten der Erdölförderländer sein. Sozio-ökonomisch gesehen selbst noch Entwicklungsländer, wachsen die Erdölförderländer wegen ihrer steigenden Leistungsbilanzüberschüsse in die Mitverantwortung für die Masse der typischerweise exportschwachen Entwicklungsländer hinein.

Selbst wenn aber UNCTAD in den kommenden Jahren die in sie gesetzten hochgespannten Erwartungen enttäuschen sollte, so wäre dies zum guten Teil auf ihre Erfolge zurückzuführen. UNCTAD hat Ost, West und Süd zur Lösung konkreter Probleme der Weltwirtschaftsordnung an einen Tisch gebracht, dem Süden ein erhebliches Eigengewicht verschafft und dem Prinzip der sozialen Mitverantwortung im Weltmaßstab zur Anerkennung verholfen. Als entscheidender internationaler Integrationsfaktor konnte UNCTAD den Weg zu einer weltweiten Entwicklungsplanung bereiten, wie sie sich mit der Zweiten Entwicklungsdekade der Vereinten Nationen abzeichnet.

Mit der Institutionalisierung des Gruppensystems schafft UNCTAD ein neues Ordnungsprinzip für die internationalen Wirtschaftsbeziehungen, das auf der Grundlage autonomer Gruppenbildung im Süden tendenziell zu einer Abschwächung der gegenwärtig noch vorherrschenden hegemonialen Großraumordnung beiträgt.

UNCTAD wird nach grundsätzlicher Anerkennung einiger ihrer Hauptanliegen vielleicht das Pathos der „Klassenkampforganisation“ einbüßen, dafür aber bei der praktischen Verwirklichung ihrer Ziele weniger „ideologischen“ Widerstand von seiten führender westlicher Industriestaaten zu befürchten haben. Das unerhört weitreichende Problem der Einbeziehung der multinationalen Unternehmen in die 
soziale Verantwortung könnte das zentrale Thema von UNCTAD für die nächsten zehn Jahre werden. Die Probleme angemessener Besteuerung von Konzerntöchtern, die inhaltliche Gestaltung von Konzessions- und Investitionsförderungsverträgen sowie wettbewerbsrechtliche Fragen dürften dabei in den Vordergrund rücken. Die gemeinsame Auseinandersetzung mit dem Phänomen der multinationalen Unternehmen wird eventuell sogar zu einem breiteren Konsensus innerhalb von UNCTAD führen. Bei der Lösung dieser Probleme wird UNCTAD in jedem Falle den Ruf eines Integrationsfaktors ersten Ranges für die Verwirklichung der Idee einer Weltsozialgemeinschaft zu verteidigen haben. 


\section{ANHANG I}

\section{UNCTAD I - Allgemeine Prinzipien}

\section{General Principles}

\section{General Principle One ${ }^{1}$}

Economic relations between countries, including trade relations, shall be based on respect for the principle of sovereign equality of States, self-determination of peoples, and non-interference in the internal affairs of other countries.

General Principle Two 2

There shall be no discrimination on the basis of differences in socio-economic systems. Adaptation of trading methods shall be consistent with this principle.

\section{General Principle Three ${ }^{3}$}

Every country has the sovereign right freely to trade with other countries, and freely to dispose of its natural resources in the interest of the economic development and well-being of its own people.

1 General Principle One was adopted by a roll-call vote of 113 to 1, with 2 abstentions:

In favour: Afghanistan, Albania, Algeria, Argentina, Australia, Austria, Belgium, Bolivia, Brazil, Bulgaria, Burma, Burundi, Byelorussain Soviet Socialist Republic, Combodia, Cameroon, Canada, Central African Republic, Ceylon, Chad, Chile, China, Colombia, Congo (Brazzaville), Congo (Leopoldville), Cuba, Cyprus, Czechoslovakia, Denmark, Dominican Republic, Ecuador, Ethiopia, Federal Republic of Germany, Finland, France, Gabon, Ghana, Greece, Guatemala, Guinea, Haiti, Holy See, Honduras, Hungary, Iceland, India, Indonesia, Iran, Iraq, Ireland, Israel, Italy, Ivory Coast, Jamaica, Japan, Jordan, Kenya, Kuwait, Laos, Lebanon, Liberia, Libya, Liechtenstein, Luxembourg, Madagascar, Malaysia, Mali, Mauritania, Mexico, Monaco, Mongolia, Morocco, Nepal, Netherlands, New Zealand, Nicaragua, Niger, Nigeria, Norway, Pakistan, Panama, Paraguay, Peru, Philippines, Poland, Republic of Korea, Republic of Viet-Nam, Romania, Rwanda, San Marino, Saudi Arabia, Senegal, Sierra Leone, South Africa, Spain, Sudan, Sweden, Switzerland, Syria, Thailand, Togo, Trinidad and Tobago, Tunisia, Turkey, Uganda, Ukrainian Soviet Socialist Republic, Union of Soviet Socialist Republics, United Arab Republic, United Republic of Tanganyika and Zanzibar, Upper Volta, Uruguay, Venezuela, Yemen, Yugoslavia.

Against: United States of America.

Abstaining: Portugal, United Kingdom of Great Britain and Northern Ireland.

2 General Principle Two was adopted by a roll-call vote of 96 to 3, with 16 abstaining:

In favour: Afghanistan, Albania, Algeria, Argentina, Austria, Belgium, Bolivia, Brazil, Bulgari, Burma, Burundi, Byelorussian Soviet Socialist Republic, Cambodia, Cameroon, Central African Republic, Ceylon, Chad, Chile, Colombia, Congo (Brazzaville), Congo (Leopoldville), Cuba, Czechoslovakia, Dominican Republic, Ecuador, Ethiopia, Finland, France, Gabon, Ghana, Greece, Guatemala, Guinea, Haiti, Holy See, Honduras, Hungary, India, Indonesia, Iran, Iraq, Israel, Italy, Ivory Coast, Jamaica, Japan, Jordan, Kenya, Kuwait, Laos, Lebanon, Liberia, Libya, Luxembourg, Madagascar, Malaysia, Mali, Mauritania, Mexico, Mongolia, Morocco, Nepal, New Zealand, Nicaragua, Niger, Nigeria, Pakistan, Panama, Paraguay, Peru, Philippines, Poland, Portugal, Romania, Rwanda, San Marino, Saudi Arabia, Senegal, Sierra Leone, Sudan, Syria, Thailand, Togo, Trinidad and Tobago, Tunisia, Turkey, Uganda, Ukrainian Soviet Socialist Republic, Union of Soviet Socialist Republics, United Arab Republic, United Republic of Tanganyika and Zanzibar, Upper Volta, Uruguay, Venezuela, Yemen, Yugoslavia.

Against: Canada, Federal Republic of Germany, United States of America.

Abstaining: Australia, China, Denmark, Iceland, Ireland, Liechtenstein, Monaco, Netherlands, Norway, Republic of Korea, Republic of Viet-Nam, South Africa, Spain, Sweden, Switzerland, United Kingdom of Great Britain and Northern Ireland.

3 General Principle Three was adopted by a roll-call vote of 94 to 4, with 18 abstentions:

In favour; Afghanistan, Albania, Algeria, Argentina, Bolivia, Brazil, Bulgaria, Burma, Burundi, Byelorussian Soviet Socialist Republic, Combodia, Central African Republic, Ceylon, Chad, Chile, China, Colombia, Congo (Brazzaville), Congo (Leopoldville), Cuba, Cyprus, Czechoslovakia, Denmark, Dominican Republic, Ecuador, Ethiopia, Finland, Gabon, Ghana, Greece, Guatemala, Guinea, Haiti, Honduras, Hungary, Iceland, India, Indonesia, Iran, Iraq, Israel, Ivory Coast, Jamaica, Jordan, Kenya, Kuwait, Laos, Lebanon, Liberia, Libya, Madagascar, Malaysia, Mali, Mauritania, Mexico, Mongolia, Morocco, Nepal, Niger, Nigeria, Norway, Pakistan, Panama, Paraguay, Philippines, Poland, Portugal, Republic of Korea Republic of Viet-Nam, Romania, Rwanda, San Marino, Saudi Arabia, Senegal, Sierra Leone, Spain, Sudan, Sweden, Syria, Thailand, Togo, Trinidad and Tobago, Tunisia, Turkey, Uganda, Ukrainian Soviet Socialist Republic, Union of Soviet Socialist Republics, United Arab Republic, United Republic of Tanganyika and Zanzibar, Upper Volta, Uruguay, Venezuela, Yemen, Yugoslavia.

Against: Australia, Canada, United Kingdom of Great Britain and Northern Ireland, United States of America.

Abstaining: Austria, Belgium, Cameroon, Federal Republic of Germany, France, Holy See, Ireland, Italy, Japan, Liechtenstein, Luxembourg, Monaco, Netherlands, New Zealand, Nicaragua, Peru, South Africa, Switzerland. 


\section{General Principle Four ${ }^{4}$}

Economic development and social progress should be the common concern of the whole international community and should, by increasing economic prosperity and well-being, help strengthen peaceful relations and co-operation among nations. Accordingly, all countries pledge themselves to pursue internal and external economic policies designed to accelerate economic growth throughout the world, and in particular to help promote, in developing countries, a rate of growth consistent with the need to bring about a substantial and steady increase in average income, in order to narrow the gap between the standard of living in developing countries and that in the developed countries.

General Principle Five ${ }^{5}$

National and international economic policies should be directed towards the attainment of an international division of labour in harmony with the needs and interests of developing countries in particular, and of the world as a whole. Developed countries should assist the developing countries in their efforts to speed up their economic and social progress, should co-operate in measures taken by developing countries for diversifying their economies, and should encourage appropriate adjustments in their own economies to this end.

4 General Principle Four was adopted by a roll-call vote of 98 to 1 , with 17 abstentions:

In favour: Afghanistan, Albania, Algeria, Argentina, Austria, Bolivia, Brazil, Bulgaria, Burma, Buruna, Byelorussian Soviet Socialist Republic, Cambodia, Cameroon, Central African Republic, Ceylon, Chad, Chile, China, Colombia, Congo (Brazzaville), Congo (Leopoldville), Cuba, Cyprus, Czechoslovakia, Denmark, Dominican Republic, Ecuador, Ethiopia, Gabon, Ghana, Greece, Guatemala, Guinea, Haiti, Holy See, Honduras, Hungary, Iceland, India, Indonesia, Iran, Iraq, Israel, Ivory Coast, Jamaica, Jordan, Kenya, Kuwait, Laos, Lebanon, Liberia, Libya, Madagascar, Malaysia, Mali, Mauritania, Mexico, Mongolia, Morocco, Nepal, New Zealand, Nicaragua, Niger, Nigeria, Norway, Pakistan, Panama, Paraguay, Peru, Philippines, Poland, Portugal, Republic of Korea, Republic of Viet-Nam, Romania, Rwanda, Saudi Arabia, Senegal, Sierra Leone, Spain, Sudan, Sweden, Syria, Thailand, Togo, Trinidad and Tobago, Tunisia, Turkey, Uganda, Ukrainian Soviet Socialist Republic, Union of Soviet Socialist Republics, United Arab Republic, United Republic of Tanganyika and Zanzibar, Upper Volta, Uruguay, Venezuela, Yemen, Yugoslavia.

Against: United States of America.

Abstaining: Australia, Belgium, Canada, Federal Republic of Germany, Finland, France, Ireland, Italy, Japan, Liechtenstein, Luxembourg, Monaco, Netherlands, San Marino, South Africa, Switzerland, United Kingdom of Great Britain and Northern Ireland.

5 General Principle Five was adopted by a roll-call vote of 97 to none, with 19 abstentions:

In favour: Afghanistan, Albania, Algeria, Argentina, Austria, Bolivia, Brazil, Bulgaria, Burma, Burundi, Byelorussian Soviet Socialist Republic, Cambodia, Cameroon, Central African Republic, Ceylon, Chad, Chile, China, Colombia, Congo (Brazzaville), Congo (Leopoldville), Cuba, Cyprus, Czechoslovakia, Denmark, Dominican Republic, Ecuador, Ethiopia, Gabon, Ghana, Greece, Guatemala, Guinea, Haiti, Holy See, Honduras, Hungary, Iceland, India, Indonesia, Iran, Iraq, Israel, Ivory Coast, Jamaica, Jordan, Kenya, Kuwait, Laos, Lebanon, Liberia, Libya, Madagascar, Malaysia, Mali, Mauritania, Mexico, Mongolia, Morocco Nepal, New Zealand Nicaragua, Niger, Nigeria, Norway, Pakistan, Panama, Paraguay, Peru Philippines, Poland, Portugal, Republic of Korea, Republic of Viet-Nam, Romania, Rwanda, Saudi Arabia, Senegal, Sierra Leone, Sudan, Sweden, Syria, lic of Viet-Nam, Romania, Rwanda, Saudi Arabia, Senegal, Sierra Leone, Sudan, Sweden, Syria,
Thailand, Togo, Trinidad and Tobago, Tunisia, Turkey, Uganda, Ukrainian Soviet Socialist Republic, Union of Soviet Socialist Republics, United Arab Republic, United Republic of Tanganyika and Zanzibar, Upper Volta, Uruguay, Venezuela, Yemen, Yugoslavia.

Against: None.

Abstaining: Australia, Belgium, Canada, Federal Republic of Germany, Finland, France, Ireland, Italy, Japan, Liechentenstein, Luxembourg, Monaco, Netherlands, San Marino, South Africa, Spain, Switzerlapan, Liechentenstein, Luxembourg, Monaco, Netherlands, San Marino, South Africa,

6 General Principle Six was adopted by a roll-call vote of 114 to 1 , with 1 abstention:

In favour: Afghanistan, Albania, Algeria, Argentina, Australia, Austria, Belgium, Bolivia, Brazil, Bulgaria, Burma, Burundi, Byelorussian Soviet Socialist Republic, Cambodia, Cameroon, Canada, Central African Republic, Ceylon, Chad, Chile, Colombia, Congo (Brazzaville), Congo (Leopoldville), Cuba, Cyprus, Czechoslovakia. Denmark, Dominican Republic, Ecuador, Ethiopia, Federal Republic of Germany, Finland, France, Gabon, Ghana, Greece, Guatemala, Guinea, Haiti, Holy See, Honduras, Hungary, Iceland, India, Indonesia, Iran, Irag, Ireland, Israel, Italy, Ivory Coast, Jamaica, Japan, Jordan, Kenya, Kuwait, Laos, Lebanon, Liberia, Libya, Liechtenstein, Luxembourg, Madagascar, Malaysia, Mali, Mauritania, Mexico, Monaco, Mongolia, Morocco, Nepal, Netherlands, New Zealand, Nicaragua, Niger, Nigeria, Norway, Pakistan, Panama, Paraguay, Peru, Philippines, Poland, Portugal, Republic of Korea, Republic of Viet-Nam, Romania, Rwanda, San Marino, Saudi Arabia, Senegal, Sierra Leone, South Africa, Spain, Sudan, Sweden, Switzerland, Syria, Thailand, Togo, Trinidad and Tobago, Tunisia, Turkey, Uganda, Ukrainian Soviet Socialist Republic, Union of Soviet Socialist Republics, United Arab Republic, United Kingdom of Great Britain and Northern Ireland, United Republic of Tanganyika and Zanzibar, Upper Volta, Uruguay, Venezuela, Yemen, Yugoslavia. Against: United States of America.

Abstaining: China. 


\section{General Principle Six ${ }^{6}$}

International trade is one of the most important factors in economic development. It should be governed by such rules as are consistent with the attainment of economic and social progress and should not be hampered by measures incompatible therewith. All countries should co-operate in creating conditions of international trade conducive, in particular, to the achievement of a rapid increase in the export earnings of developing countries and, in general, to the promotion of an expansion and diversification of trade between all countries, whether at similar levels of development, at different levels of development, or having different economic and social systems.

General Principle Seven ${ }^{7}$

The expansion and diversification of international trade depends upon increasing access to markets, and upon remunerative prices for the exports of primary products. Developed countries shall progressively reduce and eliminate barriers and other restrictions that hinder trade and consumption of products from developing countries and take positive measures such as will create and increase markets for the exports of developing countries. All countries should co-operate through suitable international arrangements, on an orderly basis, in implementing measures designed to increase and stabilize primary commodity export earnings, particularly of developing countries, at equitable and remunerative prices and to maintain a mutually acceptable relationship between the prices of manufactured goods and those of primary products.

General Principle Eight ${ }^{8}$

International trade should be conducted to mutual advantage on the basis of the most-favoured-nation treatment and should be free from measures detrimental to the trading interests of other countries. However, developed countries should grant concessions to all developing countries and extend to developing countries all concessions they grant to one another and should not, in granting these or other concessions, require any concessions in return from developing countries. New

7 General Principle Seven, as amended, was adopted by a roll-call vote of 87 to 8 , with 19 abstentions: In favour: Afghanistan, Albania, Algeria, Argentina, Bolivia, Bulgaria, Burma, Burundi, Byelorussian Soviet Socialist Republic, Cambodia, Cameroon, Central African Republic, Ceylon, Chad, Chile, China, Colombia, Congo (Leopoldville), Cuba, Cyprus, Czechoslovakia, Dahomey, Dominican Republic, Ecuador, Ethiopia, Gabon, Ghana, Guinea, Haiti, Holy See, Honduras, Hungary, India, Indonesia, Iran, Iraq, Israel, Ivory Coast, Jamaica, Jordan, Kenya, Kuwait, Laos, Lebanon, Liberia, Libya, Madagascar, Malaysia, Mali, Mauritania, Mexico, Mongolia, Morocco, Nepal, Nicaragua, Niger, Nigeria, Pakistan, Panama, Paraguay, Peru, Philippines, Poland, Republic of Korea, Republic of Viet-Nam, Romania, Rwanda, Saudi Arabia, Senegal, Sierra Leone, Sudan, Syria, Thailand, Togo, Trinidad and Tobago, Tunisia, Turkey, Uganda, Ukrainian Soviet Socialist Republic, Union of Soviet Socialist Republics, United Arab Republic, United Republic of Tanganyika and Zanzibar, Upper Volta, Uruguay, Venezuela, Yemen, Yugoslavia.

Against: Australia, Canada, Denmark, Liechtenstein, South Africa, Switzerland, United Kingdom of Great Britain and Northern Ireland, United States of America.

Abstaining: Austria, Belgium, Brazil, Federal Republic of Germany, Finland, France, Greece, Iceland, Ireland, Italy, Japan, Luxembourg, Netherlands, New Zealand, Norway, Portugal, San Marino, Spain, Sweden.

8 General Principle Eight was adopted by a roll-call vote of 78 to 11 , with 23 abstentions:

In favour: Afghanistan, Albania, Algeria, Argentina, Bolivia, Bulgaria, Burma, Burundi, Byelorussian Soviet Socialist Republic, Cambodia, Cameroon, Central African Republic, Ceylon, Chad, Chile, Colombia, Congo (Leopoldville), Cuba, Cyprus, Czechoslovakia, Ecuador, Ethiopia, Gabon, Ghana, Guatemala, Guinea, Haiti, Hungary, India, Indonesia, Iran, Iraq, Israel, Ivory Coast, Jamaica, Jordan, Kenya, Kuwait, Laos, Lebanon, Liberia, Libya, Madagascar, Malaysia, Mali, Mauritania, Mexico, Mongolia, Morocco, Nepal, Nicaragua, Niger, Nigeria, Pakistan, Panama, Paraguay, Peru, Philippines, Poland, Republic of Korea, Romania, Saudi Arabia, Senegal, Sierra Leone, Sudan, Syria, Thailand, Togo, Trinidad and Tobago, Tunisia, Ukrainian Soviet Socialist Republic, Union of Soviet Socialist Republics, United Arab Republic, United Republic of Tanganyika and Zanzibar, Upper Volta, Uruguay, Yemen, Yugoslavia.

Against: Australia, Austria, Canada, Iceland, Liechtenstein, Norway, South Africa, Sweden, Switzerland, Against: Australia, Austria, Canada, Iceland, Liechtenstein, Norway, South Africa,
United Kingdom of Great Britain and Northern Ireland, United States of America.

Abstaining: Belgium, Brazil, Denmark, Federal Republic of Germany, Finland, France, Greece, Holy See, Ireland, Italy, Japan, Luxembourg, Monaco, Netherlands, New Zealand, Portugal, Republic of Viet-Nam, Rwanda, San Marino, Spain, Turkey, Uganda, Venezuela. 
preferential concessions, both tariff and non-tariff, should be made to developing countries as a whole and such preferences should not be extended to developed countries. Developing countries need not extend to developed countries preferential treatment in operation amongst them. Special preferences at present enjoyed by certain developing countries in certain developed countries should be regarded as transitional and subject to progressive reduction. They should be eliminated as and when effective international measures guaranteeing at least equivalent advantages to the countries concerned come into operation.

General Principle Nine ${ }^{9}$

Developed countries participating in regional economic groupings should do their utmost to ensure that their economic integration does not cause injury to, or otherwise adversely affect, the expansion of their imports from third countries, and, in particular, from developing countries, either individually or collectively.

General Principle Ten ${ }^{\mathbf{1 0}}$

Regional economic groupings, integration or other forms of economic cooperation should be promoted among developing countries as a means of expanding their intra-regional and extra-regional trade and encouraging their economic growth and their industrial and agricultural diversification, with due regard to the special features of development of the various countries concerned, as well as their economic and social systems. It will be necessary to ensure that such cooperation makes an effective contribution to the economic development of these countries, and does not inhibit the economic development of other developing countries outside such groupings.

9 General Principle Nine was adopted by a roll-call vote of 106 to none, with 10 abstentions:

In favour: Afghanistan, Albania, Algeria, Argentina, Australia, Austria, Bolivia, Brazil, Bulgaria, Burma, Burundi, Byelorussian Soviet Socialist Republic, Cambodia, Cameroon, Canada, Central African Republic, Ceylon, Chad, Chile, China, Colombia, Congo (Brazzaville), Congo (Leopoldville), Cuba, Cyprus, Czechoslovakia, Denmark, Dominican Republic, Ecuador, Ethiopia, Finland, Gabon, Ghana, Guatemala, Guinea, Haiti, Holy See, Honduras, Hungary, Iceland, India, Indonesia, Iran, Iraq, Ireland, Israel, Ivory Coast, Jamaica, Japan, Jordan, Kenya, Kuwait, Laos, Lebanon, Liberia, Libya, Liechtenstein, Madagascar, Malaysia, Mali, Mauritania, Mexico, Mongolia, Morocco, Nepal, New Zealand, Nicaragua, Niger, Nigeria, Norway, Pakistan, Panama, Paraguay, Peru, Philippines, Poland, Portugal, Republic of Korea, Republic of Viet-Nam, Romania, Rwanda, Saudi Arabia, Senegal, Sierra Leone, South Africa, Spain, Sudan, Sweden, Switzerland, Syria, Thailand, Togo, Trinidad and Tobago, Tunisia, Uganda, Ukrainian Soviet Socialist Republic, Union of Soviet Socialist Republics, United Arab Republic, United Kingdom of Great Britain and Northern Ireland, United Republic of Tanganyika and Zanzibar, United States of America, Upper Volta, Uruguay, Venezuela, Yemen, Yugoslavia.

Against: None.

Abstaining: Belgium, Federal Republic of Germany, France, Greece, Italy, Luxembourg, Monaco, Netherlands, San Marino, Turkey.

10 General Principle Ten was adopted by a roll-call vote of 115 to none, with 1 abstention:

In favour: Afghanistan, Albania, Algeria, Argentina, Australia, Austria, Belgium, Bolivia, Brazil, Bulgaria, Burma, Burundi, Byelorussian Soviet Socialist Republic, Cambodia, Cameroon, Canada, Central African Republic, Ceylon, Chad, Chile, China, Colombia, Congo (Brazzaville), Congo Central African Republic, Ceylon, Chad, Chile, China, Colombia, Congo (Brazzaville), Congo Federal Republic of Germany, Finland, France, Gabon, Ghana, Greece, Guatemala, Guinea, Haiti, Holy See, Honduras, Hungary, Iceland, India, Indonesia, Iran, Iraq, Ireland, Israel, Italy, Ivory Coast, Jamaica, Jordan, Kenya, Kuwait, Laos, Lebanon, Liberia, Libya, Liechtenstein, Luxembourg, Madagascar, Malaysia, Mali, Mauritania, Mexico, Monaco, Mongolia, Morocco, Nepal, Netherlands, New Zealand, Nicaragua, Niger, Nigeria, Norway, Pakistan, Panama, Paraguay, Peru, Philippines, Poland, Portugal, Republic of Korea, Republic of Viet-Nam, Romania, Rwanda, San Marino, Saudi Arabia, Senegal, Sierra Leone, South Africa, Spain, Sudan, Sweden, Switzerland, Syria, Thailand, Togo, Trinidad and Tobago, Tunisia, Turkey, Uganda, Ukrainian Soviet Socialist Republic, Union of Soviet Socialist Republics, United Arab Republic, United Kingdom of Great Britain and Northern Ireland, United Republic of Tanganyika and Zanzibar, United States of America, Upper Volta, Uruguay, Venezuela, Yemen, Yugoslavia.

Against: None.

Abstaining: Japan.

11 General Principle Eleven was adopted by a roll-call vote of 92 to 5, with 19 abstentions:

In favour: Afghanistan, Albania, Algeria, Argentina, Bolivia, Brazil, Bulgaria, Burma, Burundi, Byelorussian Soviet Socialist Republic, Cambodia, Cameroon, Central African Republic, Ceylon, Chad, Chile, China, Colombia, Congo (Brazzaville), Congo (Leopoldville), Cuba, Cyprus, Czechoslovakia, Dominican Republic, Ecuador, Ethiopia, Gabon, Ghana, Greece, Guatemala, Guinea, Haiti, Holy See, Honduras, Hungary, India, Indonesia, Iran, Iraq, Israel, Ivory Coast, Jamaica, Jordan, 


\section{General Principle Eleven ${ }^{11}$}

International institutions and developed countries should provide an increasing net flow of international financial, technical and economic assistance to support and reinforce, by supplementing the export earnings of developing countries, the efforts made by them to accelerate their economic growth through diversification, industrialization and increase of productivity, on the basis of their national policies, plans and programmes of economic development. Such assistance should not be subject to any political or military conditions. This assistance, whatever its form and from whatever source, including foreign public and private loans and capital, should flow to developing countries on terms fully in keeping with their trade and development needs. International financial and monetary policies should be designed to take full account of the trade and development needs of developing countries.

\section{General Principle Twelve ${ }^{12}$}

All countries recognize that a significant portion of resources released in successive stages as a result of the conclusion of an agreement on general and complete disarmament under effective international control should be allocated to the promotion of economic development in developing countries.

\section{General Principle Thirteen ${ }^{13}$}

The Conference decided to include, as a separate part of the Principles adopted by the Conference, the Principles relating to the transit trade of land-locked countries set forth in Annex A.I.2 below.

Kenya, Kuwait, Laos, Lebanon, Liberia, Libya, Madagascar, Malaysia, Mali, Mauritania, Mexico, Mongolia, Morocco, Nepal, New Zealand, Nicaragua, Niger, Nigeria, Pakistan, Panama, Paraguay, Peru, Philippines, Poland, Portugal, Republic of Viet-Nam, Romania, Rwanda, Saudi Arabia, Senegal, Sierra Leone, Spain, Sudan, Syria, Thailand, Togo, Trinidad and Tobago, Tunisia, Turkey, Uganda, Sierra Leone, Spain, Sudan, Syria, Thailand, Togo, Trinidad and Tobago, Tunisia, Turkey, Uganda,
Ukrainian Soviet Socialist Republic, Union of Soviet Socialist Republics, United Arab Republic. United Republic of Tanganyika and Zanzibar, Upper Volta, Uruguay, Venezuela, Yemen, Yugoslavia.

Against: Australia, Federal Republic of Germany, South Africa, United Kingdom of Great Britain and Northern Ireland, United States of America.

Abstaining: Austria, Belgium, Canada, Denmark, Finland, France, Iceland, Ireland, Italy, Japan, Liechtenstein, Luxembourg, Monaco, Netherlands, Norway, Republic of Korea, San Marino, Sweden, Switzerland.

12 General Principle Twelve was adopted by a roll-call vote of 83 to 1, with 30 abstentions:

In favour: Afghanistan, Albania, Algeria, Argentina, Bolivia, Brazil, Burma, Burundi, Cambodia, Cameroon, Central African Republic, Ceylon, Chad, Chile, Colombia, Congo (Brazzaville), Congo (Leopoldville), Cyprus, Dominican Republic, Ecuador, Ethiopia, France, Gabon, Ghana, Greece, Guatemala, Guinea, Haiti, Holy See, Honduras, Indonesia, Iran, Iraq, Israel, Ivory Coast, Jamaica, Japan, Jordan, Kenya, Kuwait, Laos, Lebanon, Liberia, Libya, Madagascar, Malaysia, Mali, Mauritania, Mexico, Monaco, Ma, Nur Mexico, Monaco, Morocco, Nepal, New Zealand, Nicaragua, Niger, Nigeria, Pakistan, Panama, Paraguay,
Peru, Philippines, Portugal, Republic of Korea, Republic of Viet-Nam, Romania, Rwanda, Saudi Arabia, Senegal, Sierra Leone, Spain, Sudan, Syria, Togo, Trinidad and Tobago, Tunisia, Uganda, United Arab Republic, United Republic of Tanganyika and Zanzibar, Upper Volta, Uruguay, Venezuela, Yemen, Yugoslavia.

Against: United States of America.

Abstaining: Australia, Austria, Belgium, Bulgaria, Byelorussian, Soviet Socialist Republic, Canada, China, Cuba, Czechoslovakia, Denmark, Federal Republic of Germany, Finland, Hungary, Iceland Ireland, Italy, Liechtenstein, Luxembourg, Mongolia, Netherlands, Norway, Poland, San Marino, South Africa, Sweden, Switzerland, Turkey, Ukrainian Soviet Socialist Republic, Union of Soviet Socialist Republics, United Kingdom of Great Britain and Northern Ireland.

13 General Principle Thirteen was adopted by a roll-call vote of 108 to none, with no abstentions: In favour: Afghanistan, Albania, Algeria, Argentina, Australia, Austria, Belgium, Bolivia, Brazil, African Republic, Ceylon, Chad, Chile, Colombia, Congo (Brazzaville), Congo (Leopoldville), Cuba, Cyprus, Czechoslovakia, Denmark, Dominican Republic, Ecuador, Ethiopia, Federal Republic of Germany, Finland, France, Gabon, Greece, Guatemala, Guinea, Haiti, Holy See, Hungary, Iceland India, Indonesia, Iran, Iraq, Ireland, Israel, Italy, Ivory Coast, Jamaica, Japan, Jordan, Kenya, Kuwait, Laos, Lebanon, Liberia, Libya, Liechtenstein, Luxembourg, Madagascar, Malaysia, Mali, Mauritania, Mexico, Monaco, Mongolia, Morocco, Nepal, New Zealand, Nicaragua, Niger, Nigeria, Norway, Panama, Peru, Philippines, Poland, Portugal, Republic of Korea, Republic of Viet-Nam, Romania, Rwanda, San Marino, Saudi Arabia, Senegal, Sierra Leone, South Africa, Spain, Sudan, Switzerland, Syria, Thailand, Togo, Trinidad and Tobago, Tunisia, Turkey, Uganda, Ukrainian Soviet Socialist Republic, Union of Soviet Socialist Republics, United Arab Republic, United Kingdom of Great Britain and Northern Ireland, United Republic of Tanganvika and Zanzibar, United States of America, Upper Volta, Uruguay, Venezuela, Yemen, Yugoslavia.

Abainst: None.

Abstaining: None. 


\section{General Principle Fourteen ${ }^{\mathbf{1 4}}$}

Complete decolonization, in compliance with the United Nations Declaration on the Granting of Independence to Colonial Countries and Peoples and the liquidation of the remnants of colonialism in all its forms, is a necessary condition for economic development and the exercise of sovereign rights over natural resources.

\section{General Principle Fifteen ${ }^{15}$}

The adoption of international policies and measures for the economic development of the developing countries shall take into account the individual characteristics and different stages of development of the developing countries, special attention being paid to the less developed among them, as an effective means of ensuring sustained growth with equitable opportunity for each developing country.

14 General Principle Fourteen was adopted by a roll-call vote of 90 to 2, with 22 abstentions:

In favour: Afghanistan, Albania, Algeria, Argentina, Bolivia, Brazil, Bulgaria, Burma, Burundi, Byelorussian Soviet Socialist Republic, Cambodia, Cameroon, Central African Republic, Ceylon, Chad, Chile, China, Colombia, Congo (Brazzaville), Congo (Leopoldville), Cuba, Cyprus, Czechoslovakia, Dominican Republic, Ecuador, Ethiopia, Gabon, Ghana, Greece, Guatemala, Guinea, Haiti, Honduras, Hungary, India, Indonesia, Iran, Iraq, Israel, Ivory Coast, Jamaica, Japan, Jordan, Kenya, Kuwait, Laos, Lebanon, Liberia, Libya, Madagascar, Malaysia, Mali, Mauritania, Mexico, Mongolia, Morocco, Nepal, Nicaragua, Niger, Nigeria, Pakistan, Panama, Paraguay, Peru, Philippines, Poland, Republic of Korea, Republic of Viet-Nam, Romania, Rwanda, Saudi Arabia, Senegal, Sierra Leone, Sudan, Syria, Thailand, Togo, Trinidas and Tobago, Tunisia, Turkey, Uganda, Ukrainian Soviet Socialist Republic, Union of Soviet Socialist Republics, United Arab Republic, United Republic of Tanganyika and Zanzibar, Upper Volta, Uruguay, Venezuela, Yemen, Yoguslavia.

Against: Australia, United Kingdom of Great Britain and Northern Ireland.

Abstaining: Austria, Belgium, Canada, Denmark, Federal Republic of Germany, France, Holy See, Iceland, Ireland, Italy, Liechtenstein, Luxembourg, Monaco, Netherlands, New Zealand, Norway, San Marino, South Africa, Spain, Sweden, Switzerland, United States of America.

15 General Principle Fifteen was adopted by a roll-call vote of 101 to none, with 12 abstentions:

In favour: Afghanistan, Algeria, Argentina, Australia, Austria, Belgium, Bolivia, Bulgaria, Burma, Burundi, Byelorussian Soviet Socialist Republic, Cambodia, Central African Republic, Ceylon, Chad, Chile, China, Colombia, Congo (Brazzaville), Congo (Leopoldville), Cuba, Cyprus, Czechoslovakia, Denmark, Ecuador, Ethiopia, Federal Republic of Germany, Finland, France, Gabon, Ghana, Greece, Guatemala, Guinea, Haiti, Holy See, Honduras, Hungary, India, Indonesia, Iran, Iraq, Ireland, Israel, Italy, Ivory, Coast, Jordan, Kenya, Kuwait, Laos, Lebanon, Liberia, Libya, Luxembourg, Madagascar, Malaysia, Mali, Mauritania, Mexico, Monaco, Mongolia, Morocco, Nepal, Netherlands, New Zealand, Nicaragua Niger Nigeria, Norway, Pakistan, Panam Paraguay, Peru Philippines, Poland, Portugal, Republic of Korea, Romania, San Marino, Saudi Arabia, Senegal, Sierra Leone, South Africa, Sudan, Sweden, Switzerland, Thailand, Togo, Trinidad and Tobago, Tunisia, Ukrainian Soviet Socialist Republic, Union of Soviet Socialist Republics, United Arab Republic, United Kingdom of Great Britain and Northern Ireland, United Republic of Tanganyika and Zanzibar, United States of America, Upper Volta, Uruguay, Venezuela, Yemen, Yugoslavia.

Against: None. Rwanda, Spain, Syria, Turkey. 


\section{Establishment of the United Nations Conference on Trade and Development as an organ of the General Assembly*}

\section{The General Assembly,}

Convinced that sustained efforts are necessary to raise the standards of living in all countries and to accelerate the economic growth of the developing countries,

Considering that international trade is an important instrument for economic development,

Recognizing that the United Nations Conference on Trade and Development has provided a unique opportunity to make a comprehensive review of the problems of trade and of trade in relation to economic development particularly those affecting the developing countries,

Convinced that adequate and effectively functioning organizational arrangements are essential if the full contribution of international trade to the accelerated economic growth of the developing countries is to be successfully realized through the formulation and implementation of the necessary policies,

Taking into account that the operation of existing international institutions was examined by the United Nations Conference on Trade and Development, which recognized both their contributions and their limitations in dealing with all the problems of trade and related problems of development,

Believing that all States participating in the United Nations Conference on Trade and Development should make the most effective use of institutions and arrangements to which they are or may become parties,

Convinced that, at the same time, there should be a further review of both the present and the proposed institutional arrangements, in the light of the experience of their work and activities,

Taking note of the widespread desire among developing countries for a comprehensive trade organization,

Recognizing that further institutional arrangements are necessary in order to continue the work initiated by the Conference and to implement its recommendations and conclusions,

Establishes the United Nations Conference on Trade and Development as an organ of the General Assembly in accordance with the provisions set forth in section II below;

1. The members of the United Nations Conference on Trade and Development (hereinafter referred to as the Conference) shall be those States which are Members of the United Nations or members of the specialized agencies or of the International Atomic Energy Agency.

* GA Resolutien 1995 (XIX). 
2. The Conference shall be convened at intervals of not more than three years. The General Assembly shall determine the date and location of the sessions of the Conference, taking into account the recommendations of the Conference or of the Trade and Development Board established under paragraph 4 below.

3. The principal functions of the Conference shall be:

(a) To promote international trade, especially with a view to accelerating economic development, particularly trade between countries at different stages of development, between developing countries and between countries with different systems of economic and social organization, taking into account the functions performed by existing international organizations;

(b) To formulate principles and policies on international trade and related problems of economic development;

(c) To make proposals for putting the said principles and policies into effect and to take such other steps within its competence as may be relevant to this end, having regard to differences in economic systems and stages of development;

(d) Generally, to review and facilitate the co-ordination of activities of other institutions within the United Nations system in the field of international trade and related problems of economic development, and in this regard to co-operate with the General Assembly and the Economic and Social Council with respect to the performance of their responsibilities for co-ordination under the Charter of the United Nations;

(e) To initiate action, where appropriate, in cooperation with the competent organs of the United Nations for the negotiation and adoption of multilateral legal instruments in the field of trade, with due regard to the adequacy of existing organs of negotiation and without duplication of their activities;

(f) To be available as a centre for harmonizing the trade and related development policies of Governments and regional economic groupings in pursuance of Article 1 of the Charter;

(g) To deal with any other matters within the scope of its competence.

\section{Trade and Development Board}

\section{Composition}

4. A permanent organ of the Conference, the Trade and Development Board (hereinafter referred to as the Board), shall be established as part of the United Nations machinery in the economic field.

5. The Board shall consist of fifty-five members elected by the Conference from among its membership. In electing the members of the Board, the Conference shall have full regard for both equitable geographical distribution and the desirability of continuing representation for the principal trading States, and shall accordingly observe the following distribution of seats:

(a) Twenty-two from the States listed in part A of the annex to the present resolution;

(b) Eighteen from the States listed in part B of the annex;

(c) Nine from the States listed in part $\mathrm{C}$ of the annex;

(d) Six from the States listed in part D of the annex. 
6. The lists of States contained in the annex shall be reviewed periodically by the Conference in the light of changes in membership of the Conference and other factors.

7. The members of the Board shall be elected at each regular session of the Conference. They shall hold office until the election of their successors.

8. Retiring members shall be eligible for re-election.

9. Each member of the Board shall have one representative with such alternates and advisers as may be required.

10. The Board shall invite any member of the Conference to participate, without vote, in its deliberations on any matter of particular concern to that member.

11. The Board may make arrangements for representatives of the inter-governmental bodies referred to in paragraphs 18 and 19 below to participate, without vote, in its deliberations and in those of the subsidiary bodies and working groups established by it. Such participation may also be offered to non-governmental organizations concerned with matters of trade and of trade as related to development.

12. The Board shall adopt its own rules of procedure.

13. The Board shall meet as required in accordance with its rules. It shall normally meet twice in any particular year.

\section{Functions}

14. When the Conference is not in session, the Board shall carry out the functions that fall within the competence of the Conference.

15. In particular, the Board shall keep under review and take appropriate action within its competence for the implementation of the recommendations, declarations, resolutions and other decisions of the Conference and for ensuring the continuity of its work.

16. The Board may make or initiate studies and reports in the field of trade and related problems of development.

17. The Board may request the Secretary-General of the United Nations to prepare such reports, studies or other documents as it may deem appropriate.

18. The Board shall, as required, make arrangements to obtain reports from and establish links with intergovernmental bodies whose activities are relevant to its functions. In order to avoid duplication it shall avail itself, whenever possible, of the relevant reports made to the Economic and Social Council and other United Nations bodies.

19. The Board shall establish close and continuous links with the regional economic commissions of the United Nations and may establish such links with other relevant regional inter-governmental bodies.

20. In its relations with organs and agencies within the United Nations system, the Board shall act in conformity with the responsibilities of the Economic and Social Council under the Charter, particularly those of co-ordination, and with the relationship agreements with the agencies concerned.

21. The Board shall serve as a preparatory committee for future sessions of the Conference. To that end, it shall initiate the preparation of documents, including 
a provisional agenda, for consideration by the Conference, as well as make recommendations as to the appropriate date and place for its convening.

22. The Board shall report to the Conference and it shall also report annually on its activities to the General Assembly through the Economic and Social Council. The Council may transmit to the Assembly such comments on the reports as it may deem necessary.

23. The Board shall establish such subsidiary organs as may be necessary to the effective discharge of its functions. It shall establish, in particular, the following committees:

(a) A committee on commodities which, inter alia, will carry out the functions which are now performed by the Commission on International Commodity Trade and the Interim Co-ordinating Committee for International Commodity Arrangements. In this connexion, the Interim Co-ordinating Committee shall be maintained as an advisory body of the Board;

(b) A committee on manufactures;

(c) A committee on invisibles and financing related to trade. The Board shall give special consideration to the appropriate institutional means for dealing with problems of shipping, and shall take into account the recommendations contained in annexes A.IV.21 and A.IV.22 of the Final Act of the Conference1.

The terms of reference of the latter two subsidiary bodies and any other subsidiary organs established by the Board shall be adopted after consultation with the appropriate organs of the United Nations and shall take fully into account the desirability of avoiding duplication and overlapping of responsibilities. In determining the size of the subsidiary organs and in electing their members, the Board shall take fully into account the desirability of including in the membership of these bodies member States with a special interest in the subject-matter to be dealt with by them. It may include any State member of the Conference, whether or not that State is represented on the Board. The Board will determine the terms of reference and rules of procedure of its subsidiary organs.

\section{Voting}

24. Each State represented at the Conference shall have one vote. Decisions of the Conference on matters of substance shall be taken by a two-thirds majority of the representatives present and voting. Decisions of the Conference on matters of procedure shall be taken by a majority of the representatives present and voting. Decisions of the Board shall be taken by a simple majority of the representatives present and voting.

\section{Procedures}

25. The procedures set forth in the present paragraph are designed to provide a process of conciliation to take place before voting and to provide an adequate basis for the adoption of recommendations with regard to proposals of a specific

1 See Proceedings of the United Nations Conference on Trade and Development, vol. I, Final Act and Report (United Nations publication, Sales No.: 64. II. B. 11), p. 54. 
nature for action substantially affecting the economic or financial interests of particular countries.

(a) Levels of conciliation

The process of conciliation within the meaning of the present paragraph may take place under the conditions stated with regard to proposals which are before the Conference, the Board or Committees of the Board. In the case of Committees of the Board, the process of conciliation shall apply only to those matters, if any, with respect to which a Committee has been authorized to submit, without further approval, recommendations for action.

(b) Request for conciliation

A request for conciliation within the meaning of the present paragraph may be made:

(i) In the case of proposals before the Conference, by at least ten members of the Conference;

(ii) In the case of proposals before the Board, by at least five members of the Conference, whether or not they are members of the Board;

(iii) In the case of proposals before Committees of the Board, by three members of the Committee.

The request for conciliation under the present paragraph shall be submitted, as appropriate, to the President of the Conference or to the Chairman of the Board. In the case of a request relating to a proposal before a Committee of the Board, the Chairman of the Committee concerned shall submit the request to the Chairman of the Board.

(c) Intiation of conciliation by the President or Chairman

The process of conciliation within the meaning of the present paragraph may also be initiated whenever the President of the Conference, the Chairman of the Board or the Chairman of the Committee concerned is satisfied that the required number of countries as specified in sub-paragraph (b) above are in favour of such conciliation. In cases where the process of conciliation is initiated at the level of a Committee, the Chairman of the Committee concerned shall refer the matter to the Chairman of the Board for action to be taken in accordance with sub-paragraph ( $f$ ) below.

(d) Time for request or initiation of conciliation

The request for conciliation (or the initiation of conciliation by the President or the Chairman, as the case may be) may be made only after the debate on the proposal has been concluded within the organ concerned and prior to the vote on that proposal. For the purposes of this provision, the Chairman of the organ concerned shall, at the conclusion of the debate on any proposal, afford an appropriate interval for the submission of requests for conciliation before proceeding to the vote on the proposal in question. In the event that conciliation is requested or initiated voting on the proposal in question shall be suspended and the procedures provided for below shall be followed.

(e) Subjects in regard to which conciliation is appropriate or excluded

The institution of the process of conciliation shall be automatic under the conditions stated in sub-paragraphs (b) and (c) above. The categories in (i) and (ii) below shall serve as guidelines:

(i) Appropriate for conciliation shall be proposals of a specific nature for action 
substantially affecting the economic or financial interests of particular countries in the following fields:

Economic plans or programmes or economic or social readjustments;

Trade, monetary or tariff policies, or balance of payments;

Policies of economic assistance or transfer of resources;

Levels of employment, income, revenue or investment;

Rights or obligations under international agreements or treaties.

(ii) Proposals in the following fields shall not require conciliation:

Any procedural matter;

Any proposal for study or investigation, including such proposals related to the preparation of legal instruments in the field of trade;

Establishment of subsidiary bodies of the Board within the scope of its competence;

Recommendations and declarations of a general character not calling for specific action;

Proposals involving action proposed in pursance of recommendations which were unanimously adopted by the Conference.

(f) Nomination of a conciliation committee

When a request for conciliation is made or initiated, the presiding officer of the organ concerned shall immediately inform the organ. The President of the Conference or the Chairman of the Board shall, as soon as possible, after consultation with the members of the organ concerned, nominate the members of a conciliation committee and submit the nominations for the approval of the Conference or the Board, as appropriate.

(g) Size and composition of the conciliation committee

The conciliation committee shall, as a rule, be small in size. Its members shall include countries especially interested in the matter with respect to which such conciliation was initiated and shall be selected on an equitable geographical basis.

(h) Procedure within the conciliation committee and submission of its report

The conciliation committee shall begin its work as soon as possible and it shall endeavour to reach agreement during the same session of the Conference or the Board. No vote shall take place in the conciliation committee. In the event that the conciliation committee is unable to conclude its work or fails to reach agreement at the same session of the Conference or of the Board, it shall report to the next session of the Board or of the Conference, whichever meets earlier. However, the Conference may instruct the conciliation committee appointed by it to submit its report to the following session of the Conference in the event that the committee shall not have concluded its work $\mathrm{o} r$ shall have failed to reach agreement during the same session of the Conference.

(i) Extension of the mandate of the conciliation committee

A proposal to continue a conciliation committee beyond the session at which it is required to report shall be decided by a simple majority.

(j) Report of the conciliation committee

The report of the conciliation committee shall indicate whether or not the committee was able to reach an agreement and whether or not the committee recommends a further period of conciliation. The report of the committee shall be made available to the members of the Conference. 
(k) Action on the report of the conciliation committee

The report of the conciliation committee shall have priority on the agenda of the organ to which it is submitted. If the organ adopts a resolution on the proposal which was the subject of the report of the conciliation committee, that resolution shall refer explicitly to the report of the conciliation committee and to the conclusion reached by the conciliation committee in the following form, as appropriate:

„Noting the report of the Conciliation Committee appointed on (date) (document number),

"Noting also that the Conciliation Committee (was able to reach an agreement) (recommends a further period of conciliation) (was unable to reach agreement)"

(l) Reports of the Board and of the Conference

The reports of the Board to the Conference and to the General Assembly and the reports of the Conference to the Assembly shall include, inter alia:

(i) The texts of all recommendations, resolutions and declarations adopted by the Board or the Conference during the period covered by the report;

(ii) In respect of recommendations and resolutions which are adopted after a process of conciliation, there shall also be included a record of the voting on each recommendation or resolution, together with the texts of the reports of the conciliation committees concerned. In the report, the record of voting and the texts of the reports shall normally follow the resolutions to which they pertain.

(m) Good offices of the Secretary-General of the Conference

The good offices of the Secretary-General of the Conference shall be utilized as fully as practicable in connexion with the process of conciliation.

(n) Proposals involving changes in the fundamental provisions of the present resolution

A process of conciliation shall also be applied under the terms and conditions laid down above in regard to any proposal for a recommendation to the General Assembly which would involve changes in the fundamental provisions of the present resolution. Any question as to whether a particular provision shall be considered fundamental for the purposes of the present sub-paragraph shall be determined by a simple majority of the Conference or the Board.

\section{Secretariat}

26. Arrangements shall be made, in accordance with Article 101 of the Charter, for the immediate establishment of an adequate, permanent and full-time secretariat within the United Nations Secretariat for the proper servicing of the Conference, the Board and its subsidiary bodies.

27. The secretariat shall be headed by the Secretary-General of the Conference, who shall be appointed by the Secretary-General of the United Nations and confirmed by the General Assembly.

28. Adequate arrangements shall be made by the Secretary-General of the United Nations for close co-operation and co-ordination between the secretariat of the Conference and the Department of Economic and Social Affairs, including the 
secretariats of the regional economic commissions and other appropriate units of the United Nations Secretariats as well as with the secretariats of the specialized agencies.

\section{Financial Arrangements}

29. The expenses of the Conference, its subsidiary bodies and secretariat shall be borne by the regular budget of the United Nations, which shall include a separate budgetary provision for such expenses. In accordance with the practice followed by the United Nations in similar cases, arrangements shall be made for assessments on States not members of the United Nations which participate in the Conference.

\section{Future Institutional Arrangements}

30. The Conference will review, in the light of experience, the effectiveness and further evolution of institutional arrangements with a view to recommending such changes and improvements as might be necessary.

31. To this end the Conference will study all relevant subjects, including matters relating to the establishment of a comprehensive organization based on the entire membership of the United Nations system of organizations to deal with trade and with trade in relation to development.

32. The General Assembly expresses its intention to seek advice from the Conference before making changes in the fundamental provisions of the present resolution. 


\section{Trade expansion and economic integration among developing countries, measures to be taken by developing and developed countries - including regional, sub-regional and interregional arrangements Concerted declaration on trade expansion, economic co-operation and regional integration among developing countries*}

1. The countries participating in the second United Nations Conference on Trade and Development (hereinafter calles "the Conference") reaffirm that trade expansion, economic co-operation and integration among developing countries is an important element of an international development strategy and would make an essential contribution towards their economic development.

2. The Conference recognizes that expansion of the mutual trade of developing countries and the creation of multinational markets among them would in many cases stimulate the establishment of new industries and the more economic use of existing productive capacity and would favour diversification and specialisation of the production and exports of developing countries, both agricultural and industrial, by enlarging both the range of exportable goods and the market opportunities for them. This would in turn contribute to enhancing the efficiency of production and the competitive position of developing countries' exports.

3. It is recognized that the responsibility for instituting schemes for regional integration among developing countries, or measures of trade expansion among them, rests in the first instance with the developing countries themselves.

4. It is further recognized that valuable progress in the development of trade expansion and regional economic co-operation schemes among developing countries has already been achieved and is being continued, as is evedenced by statements of the countries and the regional bodies concerned.

5. The Conference agrees that trade expansion and economic co-operation among developing countries can in no way be regarded as lessening the need for opportunities for increased exports to developed countries or for a greater contribution by the latter countries. Effective measures should be undertaken in both of these fields.

6. The Conference recognizes that the special conditions of a number of developing countries, and their geographical, economic and political situations, justify deversity in their choice of methods for trade expansion, economic co-operation and often warrant a step-by-step approach in integration. They also recognize that the expansion of trade and economic co-operation among developing countries pose special problems and encounter particular difficulties which must be taken into account. These difficulties include the inadequacy of infrastructure in the field of transport and communications; the traditional orientation of the trading and financial structures of developing countries towards trade with developed countries; differences in the level of development among the countries concerned

* TD / II / Res. / 23 = UNCTAD 23 (II). 
and the problems that trade liberalization commitments may entail for their balances of payments, for customs receipts and for existing domestic production; the relative weakness of their enterprises, of their financial systems and of their foreign exchange reserves. All these and other factors make it necessary to adopt flexible measures adapted to individual situations. The supporting action that the developed countries are determined to provide for efforts for trade expansion and economic co-operation among developing countries must consequently also be diversified and adapted to individual situations.

7. The Conference recognizes that the availability of appropriate external finance and technical assistance from developed countries and international institutions would enable developing countries to overcome more easily difficulties of the type mentioned above, and to achieve a more rapid progress in trade expansion and integration and would contribute to the special efforts that the developing countries are making at present.

8. In this regard, the Conference also recognized that further work will need to be done within the institutional framework of UNCTAD to determine the precise fields which could receive assistance.

9. The Conference recognizes that the developing countries will need technical assistance from the developed countries as well as from international institutions concerning inter-alia the various practical problems arising in negotiations for trade expansion and economic integration among developing countries; the preparation of multinational projects in the field of transport communications, energy, productive activities, manpower development, natural resources surveys; the establishment of export industries and trade promotion programmes geared to the markets of other developing countries. The Conference also recognized that where appropriate, arrangements should be made to enable skilled and experienced experts from developing countries to be made available to other developing countries.

\section{Statement of intent by developing countries}

1. Aware of the potential of trade expansion and economic integration among themselves, a large majority of developing countries presently participate in different types of schemes in Africa, Asia and Latin America and have informed the Conference of the progress they made, the difficulties they are encountering as well as the future action they intended.

2. In Africa, new treaties have recently entered into force relating to the Central African Customs and Economic Union, the East African Community and the West African Customs Union. Within the Conseil de l'Entente and the African Malagasy Common Services Organization, commitments relating to specific questions have recently become operative. Among the Maghreb countries, regional projects have been implemented and specific targets for arrangements regarding trade, industry and institutions have been set with a view to the conclusion of a treaty. The Comité Inter-Etats de la Rivière Sénégal is extending its activities beyond river basin development. Finally, in East Africa and West Africa countries are engaged in a process to enlarge the geographical framework of co-operation beyond the presently existing arrangements. 
3. In Latin America, the Central American Common Market and the Latin American Free Trade Association continue to implement their treaties and have embarked upon a process that is intended to lead to a Latin American Common Market covering the existing groupings as well as presently non-participating countries of the area. In the Caribbean area, and among the Andean countries, efforts to form sub-regional groupings are being pursued.

4. In Asia, the countries belonging to the Regional Co-operation for Development and to the Association of South East Asian Nations are determined to broaden their co-operation. In the Middle East, the decision to form an Arab Common Market is being implemented by the countries concerned.

5. One inter-regional multilateral agreement for trade expansion and economic co-operation has recently been concluded between India, United Arab Republic and Yugoslavia and is open for participation to all other developing countries.

6. Finally, a large number of developing countries have expressed their willingness to participate, in a framework jointly serviced by GATT and UNCTAD, in multilateral trade negotiations with a view to reducing their mutual trade barriers.

7. In order to ensure that trade and expansion, economic co-operation and integration have the desired effect of accelerating development in accordance with the considerations made in Part I, the developing countries state their determination to make all efforts, between now and the third session of the Conference, to negotiate or put into effect further meaningful commitments among themselves within the frameworks of their choice. These commitments will be adapted to the different circumstances existing in the various parts of the developing world.

\section{Declaration of support by the developed market economy countries General}

1. The developed market economy countries welcome the intention of the developing countries to conclude arrangements among themselves aimed at promoting economic growth and expanding their mutual trade. Developed market economy countries share the belief that trade expansion and intensified economic co-operation between developing countries should make an important contribution towards their development. They further believe that efforts in this direction which foster a rational and outward-looking expansion of production and trade, and avoid undue injury to the trading interests of third parties, including third dereloping countries, would contribute in the long run to the expansion of world trade and should promote more effective use of the resources available for development.

2. The developed market economy countries declare their general readiness to support initiatives of the developing countries to increase their trade and strengthen their economic co-operation along the lines indicated in the preceding paragraph and specifically to consider what help they can give to any concrete proposals that may be put forward. Such help can take the form of action in the field of commercial policy as well as financial aid and technical assistance.

\section{Commercial policy}

3. The developed market economy countries are ready, after examination and consultation within the appropriate international framework, to support particular trading arrangements among developing countries which are consistent with the 
objectives set out above. This support could include their acceptance of derogations from existing international trading obligations, including appropriate waivers of their rights to most-favoured-nation treatment.

\section{Financial and technical assistance}

4. The developed market economy countries are prepared to support, in the allocation of their financial and technical assistance, initiatives in regional cooperation instituted by the developing countries. The allocation of such assistance by developed market economy countries, within the framework of their individual aid policies and programmes, will depend on the merits of each proposition, particularly its scope and its potential impact on the development process, as well as the priority which the developing countries concerned attach to it.

Such measures might include:

- in the field of financial aid: assistance, to financial institutions embracing groups of developing countries, including regional and sub-regional development banks; financial assistance in the planning and implementation of regional projects; interim support for the needs of developing countries arising from obligations which they have undertaken in connection with their participation in arrangements for regional co-operation or integration; assistance to infrastructure projects related to regional integration; assistance to help the less-advanced areas of a particular group to share in its benefits;

- in the field of technical assistance: provision of assistance in the planning and implementation of regional projects including regional infrastructure projects; the loan of experienced and well-qualified experts; the training of personnel from developing countries; provision of assistance in the field of trade promotion; and exchange of information about developed countries' experiences as regards regional co-operation.

IV. Declaration of support by the socialist countries of Eastern Europe on the question of the expansion of trade and economic co-o-peration among developing countries

The socialist countries view with understanding and sympathy the efforts of the developing countries with regard to the expansion of trade and economic cooperation among themselves and, following the appropriate principles by which the socialist countries are guided in that respect, they are ready to extend their support to the developing countries.

\section{Future Programme of work and institutional arrangements}

1. As the expansion of trade and economic co-operation and integration among developing countries are considered by all the countries participating in the Conference as essential elements in the development strategy, it is important that these questions should be dealt with on a continuing basis by the international 
community which should privide the developing countries with support and encouragement in such efforts. The competence of UNCTAD to play an important role in this field by providing support and encouragement and by undertaking periodic reviews of the progress achieved, is recognized by all the participating countries.

2. The Conference agrees that appropriate institutional arrangements for continuing work on this subject on a permanent basis within the UNCTAD framework should be set up before the end of 1968. It accordingly requests the Trade and Development Board, in the light of the report of the Conference and of Working Group II, and in particular of this Concerted Declaration, and taking into consideration the relevant provisions of the Charter of Algiers and the activities of other bodies, to examine this question and to determine the necessary arrangements for further work along the above lines.

3. The Conference also invites the Secretary-General to prepare the necessary documentation to assist the Board in its consideration of the matter. 


\section{Charter of the economic rights and duties of states*}

\section{The United Nations Conference on Trade and Development}

Recalling that one of its main functions according to paragraph 3 (b) of General Assembly resolution 1995 (XIX), is "to formulate principles and policies on interational trade and related problems of economic development",

Recalling also recommendations A.I.1 and A.I.3 adopted at the first session of the Conference, as well as Conference resolution 22 (II),

Taking into account the International Development Strategy for the Second United Nations Development Decade adopted by the General Assembly of the United Nations in its resolution 2626 (XXV) of 24 October 1970, and the statements made by a country or group of countries on the Decade,

Taking note of the relevant principles contained in the Charter of Algiers ${ }^{1}$ and the Declaration of Lima²,

Noting with concern that the international legal instruments on which the economic relations between States are currently based are precarious and that it is not feasible to establish a just order and a stable world as long as the charter to duly protect the rights of all countries and in particular the developing States is not formulated,

Recalling that the Universal Declaration of Human Rights and the International Covenants on Human Rights make the full exercise of those rights dependent on the existence of a just international order and respect for the principle of selfdetermination of peoples and of the free disposition of their wealth and natural resources,

Recalling also the general, special and other principles as approved by the Conference in the recommendations adopted at tis first session,

Noting the urgency in the international community of a need to establish generally accepted norms to govern international economic relations systematically,

Considering in consequence the importance of further strengthening UNCTAD in accordance with General Assembly resolution 1995 (XIX) to ensure the full observance of these norms,

Taking note, in this context, of the important suggestion made at the 92nd plenary meeting that it would be desirable to draw up such a charter.

1. Decides to establish a working group composed of Government representatives of thirty-one member States, to draw up the text of a draft charter. The Working Group shall be appointed as soon as possible by the Secretary-General of UNCTAD in consultation with States members of the Conference;

2. Decides that the Working Group shall use as basic elements in its work:

(a) The general, special and other principles as approved by the Conference at its first session;

* TD / III / Res. / $45=$ UNCTAD 45 (III).

1 See Proceedings of the United Nations Conference on Trade and Development, Second Session, vol. I and Corr. 1 and 3 and Add. 1-2, Report and Anexex (United Nations publication, Sales No.: E. 68. II. D. 14),

2 TD $/ 143$. 
(b) Any proposals or suggestions on the subject made during the third session of the Conference;

(c) All documents mentioned above and other relevant resolutions adopted within the framework of the United Nations, particularly the International Development Strategy for the Second Development Decade:

(d) The principles contained in the Charter of Algiers and the Declaration of Lima.

3. Further decides that the draft prepared by the Working Group shall be sent to States members of the Conference in order that they can forward their suggestions, it being understood that the Working Group shall reconvene to elaborate the draft charter further in the light of comments and suggestions to be received from Governments of member States;

4. Recommends to the Trade and Development Board, that it examine, as a matter of priority, at its thirteenth session, the report of the above-mentioned Working Group, and the comments and suggestions made by member States of the Conference and transmit it with its comments to the General Assembly at its twenty-eighth session;

5. Invites the General Assembly, upon receipt of the above-mentioned report of the Trade and Development Board, and the views expressed by Governments during the consideration of the item in the General Assembly, to decide upon the opportunity and procedure for the drafting and adoption of the charter. 